\title{
Translation of Business Contract Text from English to Chinese in Functionalist Approach
}

\author{
Changhong Shao", ${ }^{1} \mathrm{Xi} \mathrm{i^{2 }}$ \\ ${ }^{1}$ School of Foreign Languages of Shandong University of Finance and Economics, Jinan, China \\ ${ }^{2}$ Shandong Institute of Highway Technician, Jinan, China \\ \{Changhong Shao, Xi Li\}419340495@qq.com, lixi_721@hotmail.com
}

Keywords: Functionalist Approach; Business English; Contract Text; Translation

\begin{abstract}
Business English translation has been a hot topic since international trading flourished around the world. This paper discusses the application of Functionalist approach in translating business contract text from English to Chinese, and proposes the skills and techniques needed in the translation process. Some business English translation strategies are guided by functionalist approach. This study is hoped to have theoretical significance in business English contract translation research and exert influence on the practice of international business communication in terms of contract text.
\end{abstract}

\section{INTRODUCTION}

With the development of Chinese economics and the flourishing of international trading, translation of business contract text from English to Chinese or from Chinese to English is more and more important and necessary for the success of international business communication. But some problems are inevitably existing in translation practice because of cultural gap and language differences. It is necessary to formulate corresponding translation strategies. This paper attempts to apply functionalist theories to the translation of business contract text from English to Chinese, discussing the principles of translating business English contract text and exploring the skills and techniques needed in the translation process. Translation principles such as accuracy, brevity, clarity and flexibility are discussed. Some business English translation strategies are proposed guided by functionalist approach, with some translation examples employed.

This study is hoped to have theoretical significance in business English contract translation research and exert influence on the practice of international business communication in terms of contract text.

\section{AN OVERVIEW OF FUNCTIONALIST APPROACH}

Functionalist translation theories were put forward by some German scholars in the 1970s, and were intended to bridge the gap between theory and practice in translation field.

The development of functional theory can be divided into three stages. The first stage is represented by Reiss, who proposes the Functional Categorization of translation criticism, which marks the beginning of Functionalism. The second stage is is the further development of Functionalism with Vermeer as the representative, who proposes the famous Skopos Theory. In the third stage, supplementary information is added to Functionalism by Nord, who suggests the translation theory of Function Plus Loyalty.

\subsection{The First Stage}

In 1971, German scholar Reiss put forward the concept of functional approach and developed a new model of translation criticism based on the functional relationship between source and target texts, which may be regarded as the starting point for the scholarly analysis of translation in Germany. Reiss's theory is regarded as equivalence theory. Reiss attaches great importance to the 
connection between type of text and language function (Baker, 2005). This marks the beginning of the translation school of Functionalism.

\subsection{The Second Stage}

In 1978, German scholar Vermeer, Reiss's student, made a breakthrough by putting forward his famous Skopos theory which is regarded as the landmark of functionalist approach to translation. Skopos Theory became the real foundation for the formation of German functionalist school (Munday, 2001). Skopos Theory focuses on the target languages and it serves as the impetus to the advance of functionalist theories.

Skopos Theory concentrates on the purpose of translation and determines a method to produce a functional adequate target text (Vermeer, 1978). When the translation process is concerned, the aim of the process is the skopos. When the result of the translation is concerned, skopos means the function of the translation version. And when the mode of the translation is concerned, it refers to the intention of the mode. It is one of the primary factors which decide the purpose of a translation project which is set for the expected receiver or the expected audience (Vermeer, 1989).

Six rules could be generalized from different perspectives to explain the Skopos Theory, that is:

(1) A translation project is determined by the skopos.

(2) As an offer of information originally provided by the source text, the target text should be oriented to the target culture and language.

(3) The target text can not be necessarily fully reversible to the source text.

(4) The target text should be coherent within the text.

(5) The target text should be coherent with the source text.

(6) The above five rules are listed in a hierarchical order from the highest to the lowest according to the degree of their binding force.

In other word, according to Skopos Theory, the most important mission of the translator is to complete the functions that original writer wants to achieve in the target culture during translation.

\subsection{The Third Stage}

Nord put forward a new theory of Function-Plus - Loyalty as a complement to Skopos theory (Nord, 2001). In this theory, a primary principle of translation is loyalty, which means that the initiator of the translation project, the assigned translator, the source text (ST) writer and target text (TT) readers should be "loyal" to each other. These are very important principles in business English translation.

From Nord's personal viewpoint, the functionalist approach should be established on two concepts. One is the translation project's function and the other is the relationship among those who are involved in the translation project. Function is the decisive factor that requires a source text be handled properly so that the intended purpose is fulfilled in the target text as well as in the target context. Loyalty is also an important factor to do a translation project well, which focuses on the appropriate handling of the relations among the translation project initiator, the assigned translator, the source text writer and the target text readers. Loyalty also plays the role of justifying the translation function through the negotiation between the translator and their clients (Nord, 2001). In Nord's opinion, the predetermined purpose of the translation project or the target text outweigh any other factors. As for the involvement of loyalty in her translation model, it aims to coordinate with the radical functionalism. Based on the principle of loyalty, Nord argues that translators have the duty to coordinate the relations between the source text and the target context as well as the relations between the source text initiator or writer and the target readers or receivers (Zhang, 2005). Loyalty allows translators to be faithful to the source context and meanwhile take the target context into consideration so that the balance between the two can be kept. Function plus loyalty is Nord's unique translation theory as well as her ideal.

Functionalist approach emphasizes completing the functions that original writer wants to achieve in the target language, and this approach could be applied to translation of business contract to realize cross-cultural communication in international trading. 


\section{FEATURES OF BUSINESS ENGLISH CONTRACT TEXT}

Business English is a kind of English variation to be applied by business subjects in international business activities to realize business goals. Business English is different from general English and is also called English for business purpose. Business English terms are also a kind of social functional variation of English language, which has its specific functions and application situations in international business activities. In other words, business English is a kind of English variation containing various business activities, recognized and accepted by people undertaking international business activities for the purpose of satisfying specific communicative needs. Briefly, business English has such characteristics as specialization, intentionality, and practicability.

As a special kind of text in business English, business English contract text not only bears the characteristics of business English but also has its own features. Business contracts have their unique language characteristics at textual, lexical and syntactical levels. The following just talks about the features of business English contract on levels of vocabulary and syntax. Generally, business English contract language is characterized by formality, preciseness and polysemy, with passive voice frequently employed.

\subsection{Formality}

Wording of business English contract text is official and standardized, short to convey its ideas. In keeping a business contract, people should follow some formal actions or procedures that are carried out as part of an official or lawful activity.

\subsection{Preciseness}

In business English contract text, such aspects as vocabulary, syntax and contents all have relatively strong specialization. Abundant professional terms are included in the vocabulary, which involves investment, finance, trade, economy and other related fields. The utilization of more precise professional terms is to enable all people to undertake business activities easily and make it convenient for people to communicate, express information exactly and undertake international business activities successfully.

\subsection{Polysemy}

Polysemy is a pervasive phenomenon in business English contract text. As we all know, the meaning of business words is closely related to its language context. One word used in different contexts or applied to different economic activity fields will derive different meanings, causing occurrence of polysemy phenomenon. For instance, in the field of insurance, "interest" usually indicates "the insured cargo", which may also indicate that "the buyer fails to pay off the debts in any account before the deadlines, therefore the buyer is required to pay the overdue interest to the seller according to the amount of unpaid debts.” in the field of international exchange.

\subsection{Passive voice}

Passive voice is frequently used in business English contract to highlight the doer or agent or to ensure that the articles stated in the contract are objective and forceful, free from the influence of personal emotions or willingness. The structure of "by+doer" is often used to emphasize the performer of the action; and the objective statement of the contract articles in passive voice is determined by the stylistic features of business English contract.

To guarantee that the lexical and syntactic styles of the translated version in target language (Chinese) match well with those of business English contracts, translators should have a good command of the language features of business contracts, and apply functional approach to business English contract translation, paying attention to the principles and strategies during translation process, which would be talked about in the following part. 


\section{APPLICATION OF FUNCTIONALIST APPROACH IN BUSINESS ENGLISH CONTRACT TRANSLATION}

According to the functional theory, translation is a certain type of communicative action whose purpose can directly influence translation process. Under the guide of functionalist theory, the function which target text achieves should be equal to the source text. To make the translation realize its skopos and achieve its functions, the translator should first be clear about the different linguistic styles of the two languages and their contexts. Therefore, it requires the translator to be target-reader oriented during translation process. In the process of translating business English contracts, their target functions should be in line with the project initiator's or the client's purpose or intention. If it fails to do so, the translator has the obligation to negotiate with the client or initiator so as to make proper changes and adjustments (Munday, 2001).

\subsection{Principles Guiding Business English Contract Translation}

Translators should observe the following principles in business English contract text translation:

\subsubsection{Accuracy}

Translation of business English contracts involves not only that of business correspondence but also advertisements, product specifications and other business texts of various different types. During translation process, the translator should thoroughly read the source text, understand conditions where it occurs, and then accurately have its important information reappeared after considering the whole meanings of the source text, to avoid any ambiguity that causes any mistake or misinterpretation of both sides.

\subsubsection{Brevity}

Brevity is another important principle in business English contract text translation. Concise language can economically and efficiently achieve communicative goal. Formal words should be used to ensure that the meaning conveyed is precise and has its executive force.

\subsubsection{Clarity}

In translation of business English contracts, accuracy principle emphasizes total conformance of information conveyed to reality, the so-called brevity principle highlights the highest efficiency of information conveyed by translation and the clarity principle emphasizes that translation expression should be proper and understandable, namely, using the best word in the best place, enabling readers to understand the meaning at the first time.

\subsubsection{Flexibility}

Proficiency in the target language is the fundamental requirement in translation of business English contract. Translators should also be equipped with flexible translation strategies and methods, which are comprehensive reflection of their translation ability. During translation, a translator should be good at observing the original text from different perspectives and solve translation problems occurring in translation process.

\subsection{Translation Strategies for Business English Contract Text}

Translation process is complicated and different problems would occur on different levels in different situations. We should have different strategies to cope with different problems. Traditional translation strategies such as literal translation and free translation are commonly known in translation strategy research. The following would provide several translation strategies on levels of vocabulary and syntactic structure, according to the language features of business English contract and the translation principles mentioned above.

\subsubsection{Avoiding Misinterpretation}

As is known, polysemy is one of the features of business English contract text, and in English, a single word may have several different meanings, easily leading to different interpretations. A common daily-used word may have another different professional meaning in business English contract text. During the process of translation, the exact professional meaning of a word should be made clear, otherwise, misinterpretation would occur. For example, 1, in translating the following business English contract text, if we are not clear about the meaning of "bond" in "bonded house" in the source text, misinterpretation would occur in target Chinese. 
Example 1: Bonded house is a building where bonded goods are kept until the customs duty has been paid and they can be collected by the importer or exported again.

In translating this business text, the meanings of the word "bond" would cause trouble. "Bond" usually has the meanings of "a certificate of debt (usually interest-bearing or discounted) that is issued by a government or corporation in order to raise money", and the issuer is required to pay a fixed sum annually until maturity and then a fixed sum to repay the principal. But in this sentence, "bonded" means "secured by written agreement" when it is related to "area", "house" or "goods" in business field. A bonded area or bonded zone is a free zone with relaxed jurisdiction of customs or related national regulations. Most commonly, a free area is a special customs territory with generally less strict customs regulations or no customs duties or controls for transshipment. And the phrase "in bond" is commonly used in this sense. If the exact meaning of this word "bond" is not made clear, the translation would fall in trouble. And the word "bond" has the same meaning in "bonded goods" as in "bonded house".

Misinterpretation of certain business English words is due to the lack of background knowledge in business field. Some words are of high frequency in daily usage, but in business field they may be words of low frequency. Therefore, mastering a considerable amount of business English vocabulary to avoid misinterpretation is very necessary and important in business English contract translation. This accords with the principle of "accuracy" and "clarity" mentioned above.

\subsubsection{Taking Professional Terms into Account}

Professional terms are frequently used in business contract, and in translation, we should consider the profession background of the wording to make the target text exact and professional.

Example 2: The invoice shall be subject to the usual trade discounts allowed by the Consignor. (Hu, 2001)

In the source text of Example 2, there is a business professional term "discount", which means the amount of money that is taken off the original price of a commodity. In Chinese, there is a corresponding equivalent business term to refer to the meaning. Therefore, this is quite easy for the translator to convey the professional meaning in the target language. And there are many business professional terms in business contract text such as "interest”, "access”, “acquisition” and "activity" and all these words have the meanings quite different from those in their daily usage. In translating business contract text, translators should take these professional terms into account.

\subsubsection{Adjusting the Voice}

It is a general rule in English that in formal documents the passive voice is used more frequently than the active voice for the purpose of making the statement more objective. However, there is no such rule in Chinese, and Chinese people are accustomed to seeing a sentence expressed in the active voice. As is mentioned in the third part, in business English contract text, passive voice is frequently used to highlight the doer or agent or to ensure that the articles stated in the contract are objective and forceful. Therefore, when translating business contract texts from English to Chinese, it is necessary for the translator to adjust the subject and the voice of the sentence. In example 3, the business English contract text is in passive voice.

Example 3: Delivery must be effected within the time stated on the purchased order, otherwise the Buyer may at its option cancel the order without cost to him, and charge the Seller for any loss incurred as a result of the latter's failure to make such delivery.

In Example 3, the passive voice of the English sentence complies with the language habit of business English. However, when translated into Chinese, this syntactic feature should not be kept in the target language as it does not conform to the language habit of Chinese. In this example, the doer is omitted in the sentence "Delivery must be effected...", and it in fact means "Delivery must be effected. by the seller". Therefore, the Chinese translation should start with the acting agent, in from of "The seller must...” to adjust the whole sentence structure and conform to Chinese habitual way of expression.

Newmark argues that "the functions of an informative text are influenced by its wording, the content of facts and ideas, contextual and non-language factors.” (Newmark, 2001). In consequence, when handling the translation of informative texts, the translators are supposed to transfer both the 
full language information and non-language meanings from the source text to the target language. As for the translation of prescriptive texts, the translator is required to reproduce the same effect created by the source text on source language readers in the target text on target language readers. Because of the differences between English and Chinese in wording and syntax, adjustment from English passive voice to Chinese active voice is a very good strategy to reproduce the same effect created by the English business text on English readers in the target Chinese text on Chinese readers.

The translation strategies mentioned above just serve as a modest spur to induce later researches to come forward with more valuable contributions.

\section{CONCLUSIONS}

To conclude, this paper makes a research on the application of Functionalist Approach in translating business contract text from English to Chinese, and talks about the skills and techniques needed in the translation process. Some business English translation strategies are explored guided by functionalist approach.

Business English contract text has its special features such as formality, preciseness and rich in polysemy on vocabulary level, and the use of passive voice is prominent feature on syntax level. Thus, in translating business English contract text, translators should observe specific translation principles such as accuracy, brevity, clarity and flexibility. Based on the analysis of the features of business English contract text and the translation principles, some business English translation strategies are proposed guided by functionalist approach, with some translation examples employed. In translation, we should cope with polysemy, adjust the voice and take professional terms into account. We should have different strategies to cope with different problems in translation. The translation strategies mentioned in this paper just serve as a modest spur to induce later researches to come forward with more valuable contributions.

This research is hoped to have theoretical significance in business English contract translation research and exert influence on the practice of international business communication in terms of contract text. This study just talks about the translation strategies on vocabulary level and syntax level without further discussion on discourse level, which needs further research in future study.

\section{REFERENCES}

[1] Baker, M., 2005. Routledge Encyclopedia of Translation Studies. Shanghai: Shanghai Foreign Language Education Press.

[2] Hu, G. S., Wang, C. H., Shen, Y. Z., 2001. Drafting and Translation of International Business Contract. Beijing: Beijing Foreign Language Press.

[3] Munday, J., 2001. Introducing Translation Studies: Theories and Applications. London and New York: Routledge.

[4] Newmark, P., 2001. A Textbook of Translation. Shanghai: Shanghai Foreign Language Education Press.

[5] Nord, C., 2001. Translating as a Purposeful Activity: Functional Approaches Explained. Shanghai: Shanghai Foreign Language Education Press.

[6] Vermeer, H. J., 1978. Translation Theories. Lebende Sprachen. 23 (3), pp.99-102.

[7] Vermeer, H. J., 1989. Skopos and Commission in Translational Action. Chesterman.

[8] Zhang, M. F., 2005. Functional Approach to Translation Research. Shanghai: Shanghai Foreign Language Education Press. 